\title{
A feasibility study of electrical energy generation from municipal solid waste in Iraq: Najaf case study
}

\author{
Othman M. Anssari ${ }^{1}$, Esam A. Alkaldy ${ }^{2}$, Naseem Almudhaffar ${ }^{3}$, \\ Abbas Nasir AlTaee ${ }^{4}$, Nabeel Salih Ali ${ }^{5}$ \\ 1,2,4,5Information Technology Research and Development Centre, University of Kufa, Iraq \\ ${ }^{2,3}$ Faculty of Engineering, University of Kufa, Iraq
}

\section{Article Info}

Article history:

Received Jun 7, 2019

Revised Jan 1, 2020

Accepted Jan 11, 2020

\section{Keywords:}

Electrical Energy

Electrical power

Energy

Gasification

Municipal solid waste

Renewable energy

Waste to energy

Waste management

\begin{abstract}
In several developing countries, the electricity crisis obstructs both socioeconomic and technological sustainable evolution. Also, it leads to reducing job availability due to shut down several industries or relocate to neighbouring countries to such an issue. A Najaf City is an important holy and tourist city in the middle of Iraq country. Indeed, waste management in An Najaf City needs to be reconsidered to be used as an energy source. In this article, we investigated and listed the waste quantity which produced recently (one year) respect to waste types and types of content. Data collected from the waste products for one year and are used as a key factor to study the feasibility of generating electrical energy from collected MSWs. The proposed model was simulated and tested respect to cost analysis factor of the suggested power plant by Homer pro simulation software. Results were very encouraging and competitive to the current energy production cost based on the production cost of the Kwh prospective among the conventional methods in Iraq. The proposed scenario provide proper and secure waste proposal technique with low-cost.
\end{abstract}

Copyright (ㅇ 2020 Institute of Advanced Engineering and Science. All rights reserved.

\section{Corresponding Author:}

Nabeel Salih Ali,

Information Technology Research and Development Center (ITRDC),

University of Kufa,

Kufa, P.O. Box (21), Najaf Governorate, Iraq.

Email: Nabeel@uokufa.edu.iq

\section{INTRODUCTION}

In the current era, shortages of the energy sources, changing the global climate, and world energy conflicts lead to negative effects to all levels of the society and threatened world stability was increasing These challenges can be decreasing the fossil fuel reserves to the growth of the world population, Global climate change, and Increased in wastes levels (solid/liquid) and can be resulted to electricity crisis. Diverse strategies have been investigated and studied to generate alternative energy [1,2]. These strategies are considered significant, especially for future world stability $[3,4]$. Hence, renewable energy sources in particular organic waste materials to energy is becoming an important attractive substitute in the near future [5,6]. Several Renewable waste materials sources are used to generate alternative energy like from agriculture [7-11], industries [12-18] and domestic [19-23]. These sources are adjustable to beneficial energy forms such as biohydrogen, biogas, bioalcohols, etc., through waste-to-energy routes (WTERs) for prospective growth of the world.

Municipal solid waste (MSW) is one of the renewable sources of energy in the traditional way. MSW points to materials discarded in urban areas which are collected and disposed of by the municipalities and it is counted a source of biomass due to it is a significant fraction of waste materials like leather, food waste, wood, and yard trimmings, and paper [24, 25]. Biogas is one of the efficient energy sources due to 
a small scale cost-effective and can be produced by using organic materials like several wastes [26]. In Iraq, although significant additions to the generation energy have been made recently and with available capacity expanding by 8 gigawatts (GW) (or 90\%) between 2012 and 2018). However, this has not been matched by improvements in the condition of the power grid or reductions of losses (technical and non-technical). Several challenges such as Iraq damage wrought by ISIS war against and constrained budgets that lead to not producing enough electricity to satisfy demand. Besides, Iraq's population is growing at a rate of over 1 million per year. Hence, electricity demand is set to double, reaching about 150 terawatt hours (TWh) (17.5 gigawatts $[\mathrm{GW}]$ average throughout the year). Thus, Iraq faces a profound need to develop its domestic energy infrastructure, in particular in the electricity sector to avoid these issues.

Several studies have been attempt in previous five years to study and analysis the possibilities for electrical energy production by using municipal solid waste via diverse aspects. In [27], presents the potential of electrical energy production by using municipal solid waste disposed in biggest Brazil cities such as São Paulo from landfill gas. The study includes two scenarios could replace $27 \%$ and $13.5 \%$ of the residential electrical energy consumption in the city. Another study in Brazilian municipalities is presented in [28], the study aims to analyse the techno-economic feasibility of municipal solid waste gasification to generate the electricity possibilities. The results of the proposed scenarios several pros such as increase the economic feasibility, providing a positive scale up gains that leads to lower installation and high benefits and lower costs as well. On another side, different researchers via several developing nations tried to study and analyse the potential of electrical power generation from MSW.

In [29], proposed an assessment study to generate electrical power from MSW in Rajshahi City Corporation Bangladesh. The study had the ability to generate electrical energy from MSW in RCC city is 5.336 MW and 10.568 MW during the years 2012 and 2025 respectively. In [30], two phases are aimed to examine waste-to-energy development and evaluate its success factors respect to modified Sweden's waste-to-energy model in Nigeria for WTE capacity enhancement purpose. The study results were the proposed model able to generate around 2.0 TWh of electricity from about 5.7 million tonnes of waste in its WTE plants in 2014. In Iraq, the study in [31] was conducted to product electrical power from MSW in Basrah Governorate which positon in in the south of Iraq. The study was able to generation electricity which will translate into approximately US\$ 69 million in revenues per year from the WTE plant. As well, it provide the maximum capacity for power generation is projected to be around $270 \mathrm{MW}$ in 2036 with discount rate of $12 \%$ of the WTE.

The key aim of this article is to examine, investigate and appraise the possibility of generating the electrical power from municipal solid waste in An Najaf City in the middle of Iraq. The waste is classified into population subgroups that used as a key factor to study the feasibility of generating electrical energy from collected MSWs. Homer pro simulation software is used to simulate and testing respect to cost analysis factor of the suggested power plant.

\section{METHODOLOGY}

\subsection{Waste in Al Najaf City}

Waste accumulation, collection and liquidation, and burning waste in the environment resulted in several diseases like serious skin infections or exposure to tetanus and other health risks in addition to it caused environmental risks such as Foul odours emitted from waste and distortion of the landscape of the city [32]. Waste management and treating in different countries done by classifying waste subgroups according to their type as a beginning (paper, cardboard, materials glass, such as glass flasks, metal materials, plastic materials, etc.). Thus, it requires a manpower effort for initial screening by workers and the second stage is to sort and classifying MSW to subgroups [33].

Al Najaf City is one of the Iraqi central provinces and is divided into multi-sections and each department concerned with the collection and transportation of waste in its area. Najaf Municipality Department is responsible for the collection and transportation of waste as well as the municipality of Kufa, Al Hayderiah, etc. Data listed below are specific to the Municipality of Najaf department. Where the city divides into six sections as shown in Figure 1. Waste in the aforementioned areas are collected and transported by Iraqi machines and workers in two kinds depends on the investment:

\subsubsection{Najaf Municipality Department workers and machines}

The total of 466 regular workers and 218 machines that include tractor and garbage trucks, in addition to 158 drivers were deployed. Table 1 lists the number of workers and machines of the Najaf Municipality. 


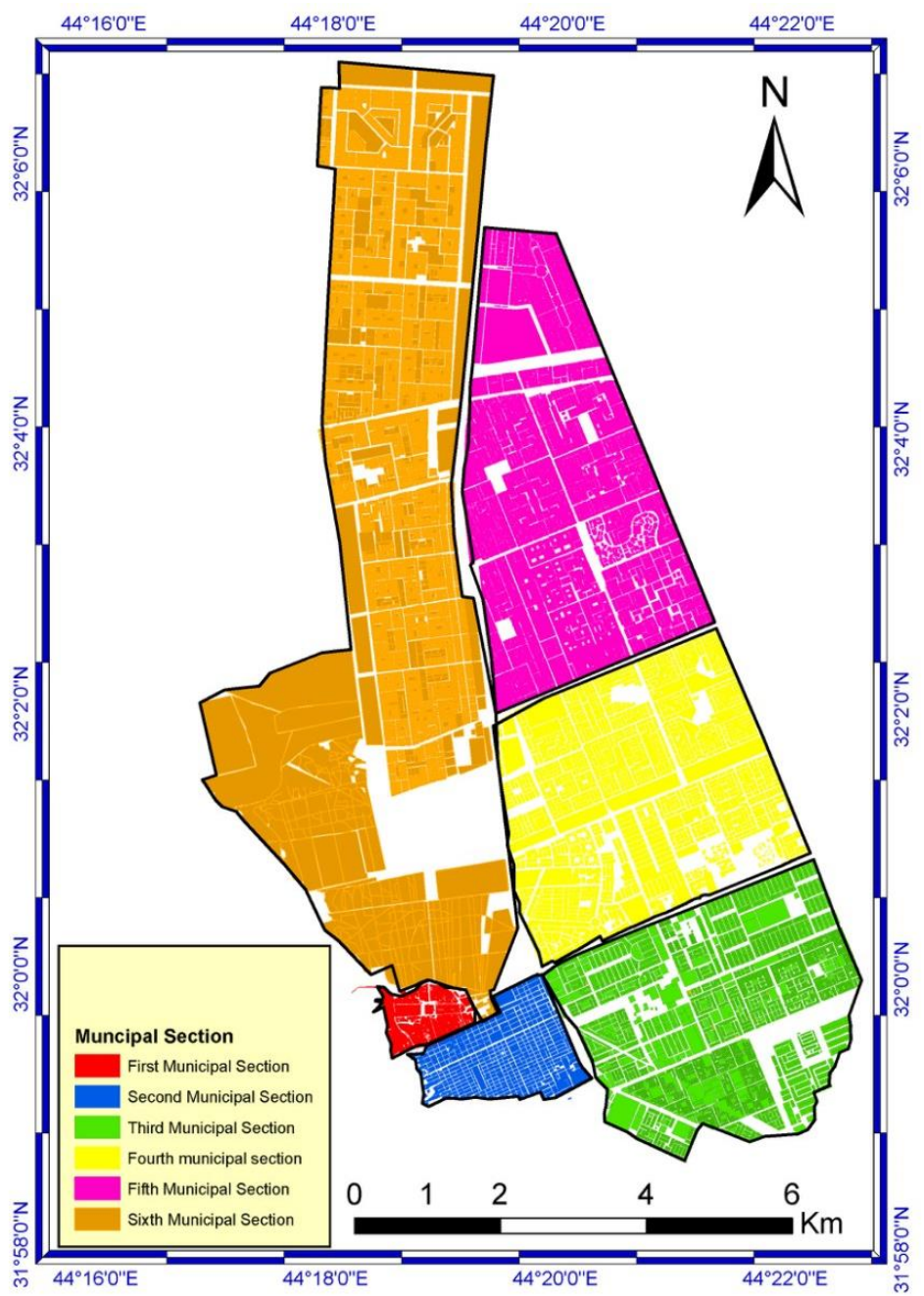

Figure 1. Six sections represent Najaf City sections

Table 1. Workers and machines in the Al Najaf Municipality Department

\begin{tabular}{lccc}
\hline Area section & Number of worker & Garbage truck & Truck \\
\hline First municipal section (Q1) & 4 & 13 & 7 \\
Second municipal section (Q2) & 14 & 19 & 10 \\
Third municipal section (Q3) & 24 & 15 & 10 \\
Fourth municipal section (Q4) & 16 & 19 & 10 \\
Fifth municipal section (Q5) & 28 & 27 & 11 \\
Sixth municipal section (Q6) & 14 & 15 & 11 \\
General Parks & 228 & 0 & 18 \\
Direct implementation & 0 & 0 & 4 \\
Landfill \& terminals & 0 & 0 & 3 \\
Mechanics \& workshops & 6 & 7 & 7 \\
Raising dust & 64 & 0 & 12 \\
Traffic engineering & 10 & & \\
\hline
\end{tabular}

\subsubsection{Najaf Governorate Council workers and machines}

The total of 620 workers and 49 garbage trucks are deployed to collect MSW as shown in Table 2. The cost which paid from Najaf governorate council to the workers and machines per month will be around $355,000,000$ three hundred fifty-five million Iraqi dinars (IQD). Based on results in Tables 1 and 2, the total workers and machines in these areas will be: 620 Najaf governorate council workers, 408 Najaf Municipality Department workers, 114 Garbage truck, 152 truck, 45 observers, and 238 divers respectively. The residential and commercial waste amount for each section (Q1 to Q6) per day and year is shown in Table 3, in addition to the 2016 population. 
Table 2 Workers and machined numbers in the Al Najaf Governorate

\begin{tabular}{|c|c|c|c|}
\hline Area & No. of workers & Number of observers & Number of tractors \\
\hline Q1 & 130 & 4 & \\
\hline Q2 & 90 & 4 & 2 \\
\hline Q3 & 94 & 4 & 13 \\
\hline Q4 & 90 & 6 & 10 \\
\hline Q5 & 134 & 10 & 14 \\
\hline Q6 & 72 & 4 & 10 \\
\hline \multicolumn{2}{|c|}{ Additional observer } & \multicolumn{2}{|c|}{7} \\
\hline \multicolumn{2}{|c|}{ Station workers } & \multicolumn{2}{|c|}{5} \\
\hline \multicolumn{2}{|c|}{ Agricultural engineer } & \multicolumn{2}{|c|}{1} \\
\hline \multicolumn{2}{|c|}{ maintenance observer } & \multicolumn{2}{|c|}{5} \\
\hline \multicolumn{2}{|c|}{ control observer } & \multicolumn{2}{|c|}{1} \\
\hline \multicolumn{2}{|c|}{ Drivers } & \multicolumn{2}{|c|}{80} \\
\hline
\end{tabular}

Table 3. The residential and commercial waste amount and 2016 population

\begin{tabular}{ccccccc}
\hline Area & $\begin{array}{c}\text { No. of Housing } \\
\text { units }\end{array}$ & $\begin{array}{c}\text { Population } \\
2016\end{array}$ & $\begin{array}{c}\text { Residential } \\
\text { units waste }\end{array}$ & $\begin{array}{c}\text { Commercial } \\
\text { units waste }\end{array}$ & $\begin{array}{c}\text { Waste } \\
\text { (ton/day) }\end{array}$ & $\begin{array}{c}\text { Waste } \\
\text { (ton/year) }\end{array}$ \\
\hline Q1 & 3058 & 21406 & 21 & 150 & 171 & 62415 \\
Q2 & 20850 & 145950 & 146 & 30 & 176 & 64240 \\
Q3 & 16793 & 117551 & 118 & 24 & 142 & 51830 \\
Q4 & 21912 & 153384 & 154 & 30 & 184 & 67160 \\
Q5 & 30303 & 212121 & 212 & 43 & 255 & 93075 \\
Q6 & 28410 & 198870 & 199 & 0 & 199 & 72635 \\
Total & 121326 & 849282 & 850 & 277 & 1127 & 411355 \\
\hline
\end{tabular}

A total number of inhabitants in these districts in 2016 is around $880 \mathrm{~K}$ (eight hundred eighty thousand people) and the total waste per day for these areas is 1127 tons (one thousand and one hundred twenty-seven tons). By dividing these amount of waste among the number of people to get the percentage of waste per each one, $1.28 \mathrm{~kg}$ per person. Directorate collects and transport wastes from the sections above to central areas in the neighbourhoods of Abu Talib and Alquds and then to the landfill area behind the Al-Nida neighbourhood.

Quantity of the waste for one year will be more than $400 \mathrm{k}$ (four hundred thousand) tons annually. This process is not beneficial to municipal departments and is consumable for them. These wastes continue to exist because there is no fixed time for waste disposal by citizens, as lifting process takes place normally in morning and evening. Waste in the city is almost consisting of paper and cardboard, glass, such as glass flasks, metal materials, plastic materials, etc. [34]. Table 4 lists the ratio of waste management regarding several materials and components.

Table 4. Waste components

\begin{tabular}{llll}
\hline Components & Percentage $\%$ & Components & Percentage \% \\
\hline Food waste & $68.17 \%$ & Textiles & $5.09 \%$ \\
Paper and cardboard & $9.6 \%$ & Baby diapers & $1.9 \%$ \\
Glass & $2.3 \%$ & Residues of gardens & $0.93 \%$ \\
Plastic and nylon & $5.29 \%$ & Wood & $0.85 \%$ \\
Food packaging & $1.42 \%$ & Rubber & $1.0 \%$ \\
Aluminum cans & $1.4 \%$ & Leather materials & $0.48 \%$ \\
Metals & $0.98 \%$ & Another & $0.59 \%$ \\
\hline
\end{tabular}

Quick steps to solve the waste problem in a timely manner are possible by providing certain types of equipment and some requirements such as:

- Select a specific area for the collection of waste in special containers.

- Distribution of waste collection bags.

- Agreement to lift containers or empty them with the contractor or by the municipality.

Above steps are mostly the choices of municipal departments in the province for waste management and it's clear that they are insufficient.

\subsection{Waste management}

There is requiring to increase the citizen's awareness to reduce, isolate, and classify waste to several types (paper, glass, plastic, etc.) to reuse it again and be more helpful for recycling [33]. Recycling refers to the process of compiling materials and sorted them by its types to be more suitable for manufacturing and reusable materials [35]. This process has many significant such as reduce pollution of the environment, 
create new job opportunities, preserving the sources of natural materials, and reduce reliance on raw materials. Thus, increased the environmental awareness of the citizen will lead to making people follow rules to avoid waste issues and benefit from their waste. Also, the distribution of different bags colours can be a classified type of waste contained (blue colour of waste plastic and green for waste food, etc.) or can divide it into simple sections by citizen (such as paper waste, plastic waste, glass waste, etc.). Based on the distribution result strategy, waste can be utilized by selling it to collection centres in the neighbourhoods (selecting a specific area for collection of waste in private containers for each neighbourhood) and waste assessed by its type and placing these amounts in the waste owner's account using prepaid card systems. Hence, this mechanism will motivate to make people high benefit from their waste disposal.

\subsection{Waste to energy (WTE)}

Several technologies have been used to disposal waste to reuse and convert waste to electricity power such [31]. These technologies such as incineration, gasification, pyrolysis, combined pyrolysis, gasification, combined gasification-combustion, and plasma gasification/verification [36]. Gasification method is selected in this study due to low capital investment, simple, and available waste disposal techniques in An Najaf City and can be a suitable technique to be deployed.

\subsection{Gasification}

Gasification is one of the methods used to treat, reuse, and convert waste via digging a hole in the ground and put the waste inside and cover it with soil afterward [37-39]. Then, the soil will absorb large amounts of waste without the need for advanced technology in addition to low cost. However, decomposition of waste leads to leakage of toxins to groundwater or surface water sources with soil pollution, which affects the agriculture and food cycle in addition to pollution of drinking water and thus increasing the dangers to the lives of citizens. In addition, it also transmitting air-polluting gases, leading to many risks to all living creatures, as it affects breathing air as well as the emission of unpleasant odours, but all disadvantages can be solved by selecting the suitable place to minimize any undesirable effects. Thus, waste should be covered with a layer of soil for maximum benefits from these gases by using biogas technology.

\section{RESULTS AND ANALYSIS}

\subsection{Case study and simulation scenario and evaluation metrics}

In this study, the collected wastes in An Najaf City for one year are used to generate electrical power and study the feasibility by simulating the case study with Homer Pro software [40, 41]. A scenario which is assumed with biogas gasifier (generator) is simulated with Homer Pro and fed with the available data of the collected waste from the six sectors of the city and with the parameters shown in the Figure 2 for one year as a timeline. Information from Table 3 is fed to the biomass source of the generator as shown in Figure 3. Information from Table 4 is used to model the biogas fuel parameters as shown in Figures 4 and 5. Average monthly temperature effect also was included in the simulation. As shown in Figure 6. The temperature data is taken from climate and weather averages in Baghdad, Iraq.

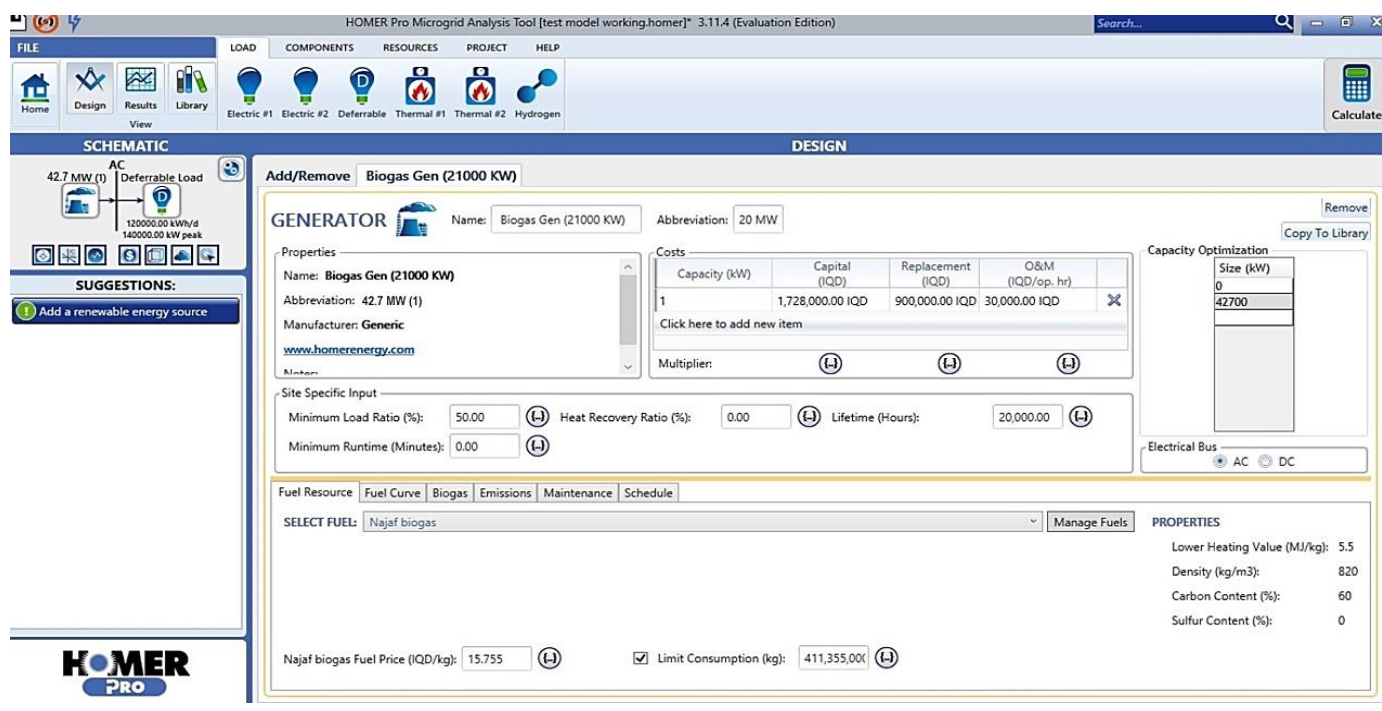

Figure 2. Homer pro micro grid analysis tool 


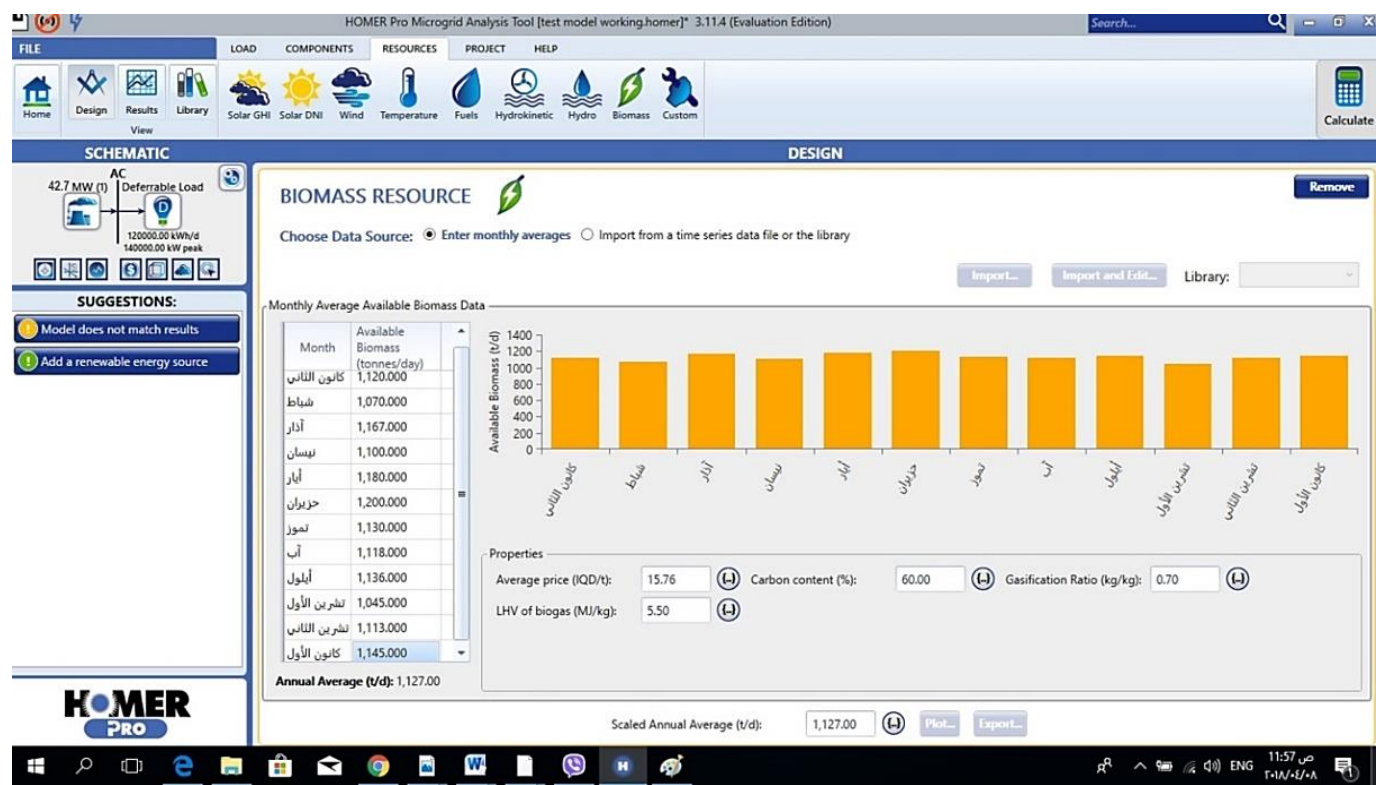

Figure 3. Biomass resource

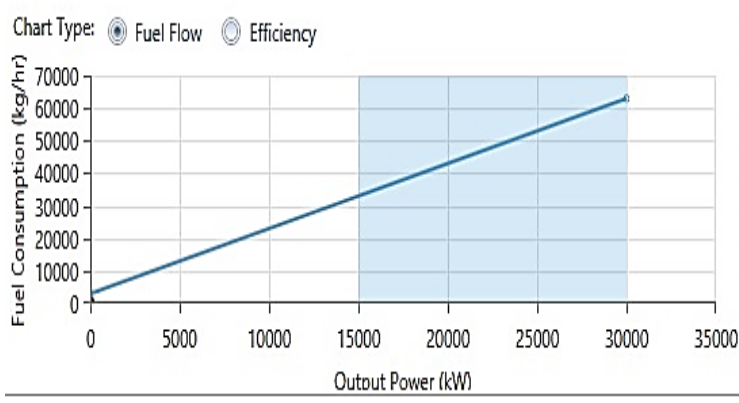

Figure 4. Fuel flow diagram (using data given in Table 3)

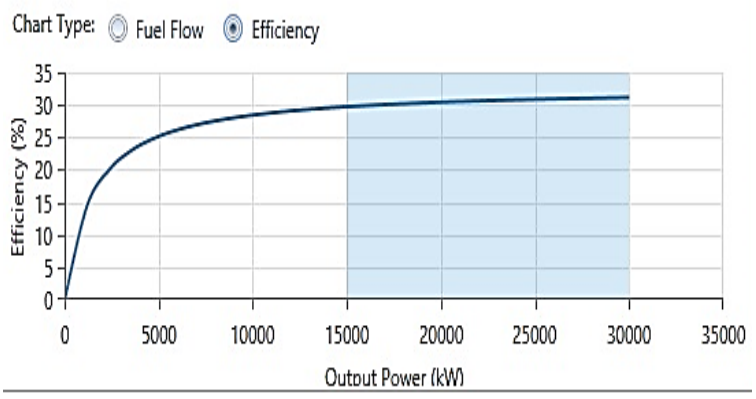

Figure 5. Fuel efficiency diagram (using data given in Table 4)

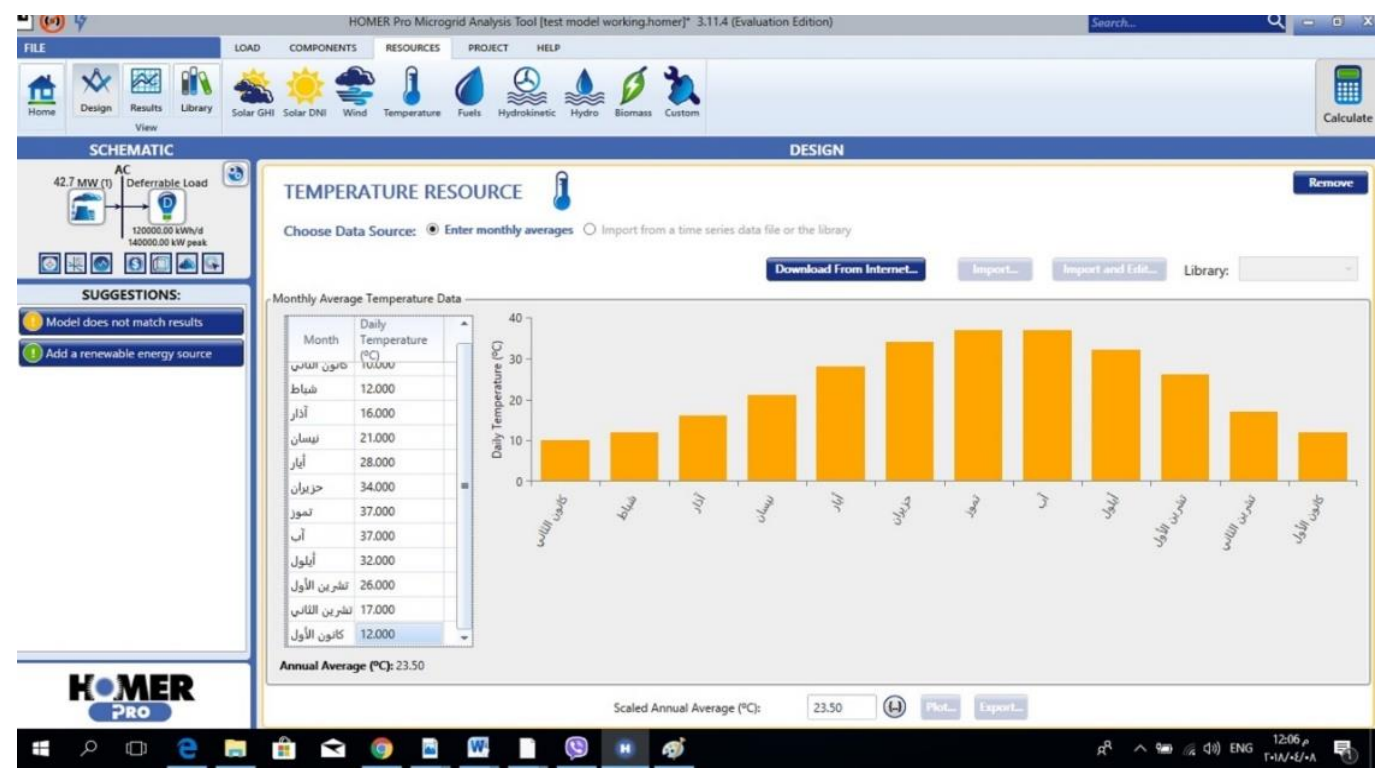

Figure 6. Temperature data average in Baghdad, Iraq 


\subsection{Simulation results}

In the feasibility study which introduced in this work (Section 3.1), the start parameter was the total amount of the collected waste per year, in Najaf City which was costed 411355 ton/year. This amount of waste costs a lot of money and efforts to properly landfill, so this amount was assumed as a fuel input for a gasification power plant simulated with Homer pro evaluation copy software. The simulation results shown in Figure 7 shows that a power plant with the given amount of waste as an input can produce around 42.7 Mega Watt and about 187 million KWh/year. The cost analysis results shown in Table 5 are very encouraging to adapt to this scenario in real settings.

The total operating cost is around 11240 Billion IQD per year which includes besides the plant's operation and maintenance cost the waste collecting cost (labors and machinery costs). Currently, the Kwh average cost produced from the conventional power plants in Iraq according to the ministry of electricity report [42] is 106 IQD. A rapid calculation can show that the average cost of $\mathrm{kWh}$ produced from the assumed plant is $60.1 \mathrm{IQD}$, and the cost difference is very noticeable. The capital cost for such a plant is around 500 USD (US Dollar) $=600000$ IQD for Kw [43], so the total initial capital cost for the assumed plant is around 25.62 Billion IQD. From the difference in the average cost of the kWh, it's clear that the refund of the capital cost will be done in three years only.

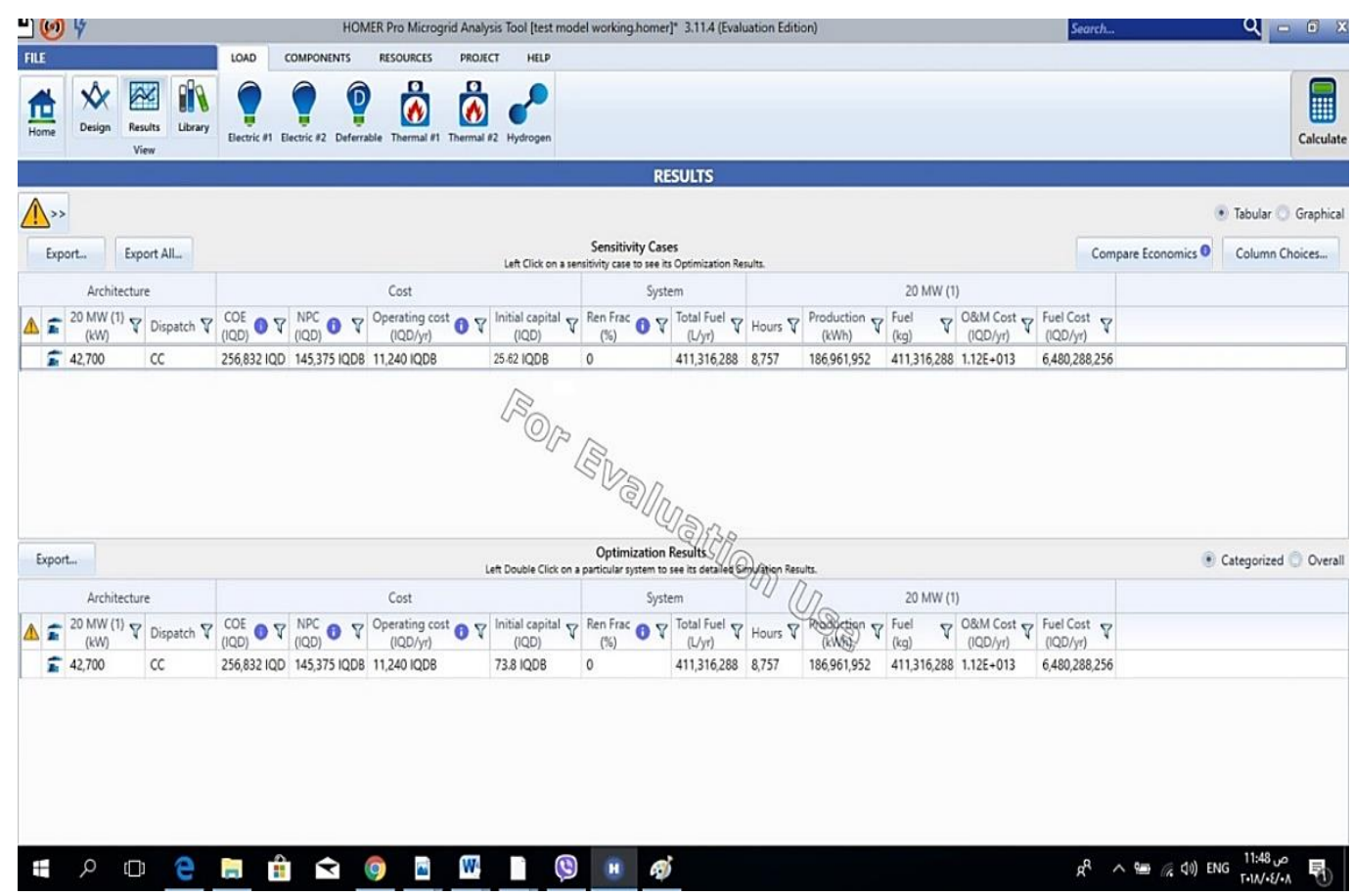

Figure 7. Homer pro simulation results

\section{CONCLUSION}

In this study, the produced waste from An Najaf City is discussed and a few remarks to manage the collection process of the waste is suggested. Currently, the waste disposal method in the city is random and cause a lot of health risks, so a feasibility study is made to find out the financial feasibility for using the waste to generate electric energy by gasification method. The total waste produced in one year is fed to a simulated gasifier with Homer pro software to calculate the produced power and the cost breakdown of it. The results have shown that the produced energy costs less than the average cost of the Kwh produced by Ministry of Electricity (MOE) Iraq with the conventional method by $(42.5 \%)$. The produced waste from 
An Najaf City can generate around 187000 Mwh/year with a 42.7 Mw plant. The initial capital cost can be refunded within three years which make the project feasible from the environmental, financial, and health point of views. The study if applied also will solve the problem of the budget of the current waste collection procedure in the city since this budget is included in the production cost of the kWh in the feasibility study.

\section{ACKNOWLEDGEMENTS}

The authors of this work would like to show there deep gratitude for the people working in the Najaf Municipality and Dr. Hussain Musa Al-Shimmary, for their help and support in accomplishing this paper.

\section{REFERENCES}

[1] K. V. S. Prasadarao, K. V. K. Rao, P. B. K. Rao, and T. Abishai, "Power Quality Enhancement in Grid Connected PV Systems using High Step up DC-DC Converter," International Journal of Electrical \& Computer Engineering, vol. 7, no. 2, pp. 720-728, 2017.

[2] I. A. Ethmane, M. Maaroufi, A. K. Mahmoud, and A. Yahfdhou, "Optimization for electric power load forecast," International Journal of Electrical and Computer Engineering, vol. 8, no. 5, 3453-3462, 2018.

[3] S. Z. A. S. K. Bahrin and S. Jaafar, "Initial development of an electrical power generator by using thermoelectric generator, focal lens and underground heat dissipation system," International Journal of Electrical and Computer Engineering, vol. 8, no. 4, pp. 2549-2556, 2018.

[4] K. Yamaguchi, K. Onishi, and K. Iida, "Wireless power transfer to a micro implant device from outside of human body," International Journal of Electrical \& Computer Engineering, vol. 9, no. 3, pp. 1541-1545, 2019.

[5] E. A. H. Alkaldy, M. A. Albaqir, and M. S. A. Hejazi, "A new load forecasting model considering planned load shedding effect," International Journal of Energy Sector Management, vol. 13, no. 1, pp. 149-165, 2019.

[6] R. Kothari, V. Tyagi, and A. Pathak, "Waste-to-energy: A way from renewable energy sources to sustainable development," Renewable and Sustainable Energy Reviews, vol. 14, no. 9, pp. 3164-3170, 2010.

[7] S. T. Alfred, "Biogas production from Calotropis procera: A latex plant fund in West Africa," Bioresource Technology, vol. 41, pp. 105-109, 1992.

[8] A. Y. Mahamat, R. Gourdon, P. Leger, and P. Vermande, "Methane recovery by anaerobic digestion of cellulosic materials available in Sahel," Biological Wastes, vol. 30, no. 3, pp. 181-197, 1989.

[9] S. K. Jain, G. S. Gujral, N. K. Jha, and P. Vasudevan, "Production of biogas from Azolla pinnata R. Br. and Lemna minor L.: Effect of heavy metal contamination," Bioresource Technology, vol. 41, no. 3, pp. 273-277, 1992.

[10] S. A. Abbasi, P. C. Nipaney, and M. B. Panholzer, "Biogas production from the aquatic weed Pistia (Pistia stratiotes)," Bioresource Technology, vol. 37, no. 3, pp. 211-214, 1991.

[11] N. Bardiya, D. Somayaji, and S. Khanna, "Biomethanation of banana peel and pineapple waste," Bioresource Technology, vol. 58, no. 1, pp. 73-76, 1996.

[12] K. Devianai and R. K. Bai, "Batch biomethanation of banana trash and coir pith, short communication," Bioresource Technology, vol. 52, no. 1, pp. 93-94, 1995.

[13] Lay J. J., "Biohydrogen generation by mesophilic anaerobic fermentation of microcrystalline cellulose," Biotechnology and Bioengineering, vol. 74, no. 4, pp. 280-287, 2001.

[14] H-S. Shin, J-H. Youn, and S-H. Kim, "Hydrogen production from food waste in anaerobic mesophilic and thermophilic acidogenesis," International Journal of Hydrogen Energy, vol. 29, no.13, pp. 1355-1363, 2004.

[15] S. Tanisho and Y. Ishiwata, "Continuous hydrogen production from molasses by fermentation using urethane foam as a support of flocks," International Journal of Hydrogen Energy, vol. 19, no. 7, pp. 541-545, 1994.

[16] H. Yu, Z. Zhu, W. Hu, and H. Zhang, "Hydrogen production from rice winery waste- water in an upflow anaerobic reactor by mixed anaerobic cultures," International Journal of Hydrogen Energy, vol. 27, no. 11-12, pp. 1359-1365, 2002.

[17] H. Yokoi, A. Saitsu, H. Uchida, J. Hirose, S. Hayashi, and Y. Takasaki, "Microbial hydrogen production sweet potato starch residue," Journal of Bioscience and Bioengineering, vol. 91, no. 1, pp. 58-63, 2001.

[18] Yokoi H, Maki R, Hirose J, Hayashi S. Microbial production of hydrogen from starch manufacturing wastes. Biomass and Bioenergy 2002; 22:389-95.

[19] S. W. van Ginkel, S-E. Oh, and B. E. Logan, "Biohydrogen production from food processing and domestic wastewaters," International Journal of Hydrogen Energy, vol. 30, no. 15, pp. 1535-1542, 2005.

[20] M. Okamoto, T. Miyahara, O. Mizuno, and T. Noike, "Biological hydrogen potential of materials characteristic of the organic fraction of municipal solid wastes," Water Science and Technology, vol. 41, no. 3, pp. 25-32, 2000.

[21] J-J. Lay, Y-J. Lee, and T. Noike, "Feasibility of biological hydrogen production from organic fraction of municipal solid waste," Water Research, vol. 33, no. 11, pp. 2579-2586, 1999.

[22] V. C. Kalia, S. R. Jain, A. Kumar, and A. P. Joshi, "Fermentation of biowaste to H2 by Bacillus licheniformis," World Journal of Microbiology and Biotechnology, vol. 10, no. 2, pp. 224-227, 1994.

[23] Jr. C. P. L. Grady, G. T. Daigger, and H. C. Lim, "Biological wastewater treatment: Biological nutrient removal," Marcel Dekker, New York, pp. 487-497, 1999.

[24] H. Cheng and Y. Hu, "Municipal solid waste (MSW) as a renewable source of energy: Current and future practices in China," Bioresource Technology, vol. 101, no. 11, pp. 3816-3824, 2010. 
[25] N. Hamzah, K. Tokimatsu, and K. Yoshikawa, "Solid fuel from oil palm biomass residues and municipal solid waste by hydrothermal treatment for electrical power generation in Malaysia: A review," Sustainability, vol. 11, no. 4, pp. 1-23, 2019.

[26] K. E. Agbo and J. I. Eze, "Anaerobic digestion of municipal solid waste for generation of energy: Prospects and challenges in Nigeria," Nigeria Journal of Solar Energy, vol. 22, pp. 130-137, 2011.

[27] S. N. M. de Souza et al., "Technical potential of electricity production from municipal solid waste disposed in the biggest cities in Brazil: Landfill gas, biogas and thermal treatment," Waste Management \& Research, vol. 32, no. 10, pp. 1015-1023, 2014.

[28] F. C. Luz et al., "Techno-economic analysis of municipal solid waste gasification for electricity generation in Brazil," Energy Conversion and Management, vol. 103, pp. 321-337, 2015.

[29] B. K. Das, Ms. A. Kader, and S. M. N. Hoque, "Energy recovery potential from municipal solid waste in Rajshahi city by landfill technique," International Journal of Renewable Energy Research, vol. 4, no. 2, pp. 349-354, 2014.

[30] P. Akhator, A. I. Obanor, and L. I. Ezemonye, "Electricity generation in Nigeria from municipal solid waste using the Swedish Wasteto-Energy Model," Journal of Applied Sciences and Environmental Management, vol. 20, no. 3, pp. 635-643, 2016.

[31] A. H. A. Abbas, W. S. Al-Rekabi, and A. N. A. Hamdan, "Prediction of potential electrical energy generation from MSW of Basrah Government," 5th International Conference on Waste Management, Ecology and Biological Sciences, Turkey, 2017.

[32] T. Jamasb and R. Nepal, "Issues and options in waste management: A social cost-benefit analysis of waste-to-energy in the UK," Resources, Conservation and Recycling, vol. 54, no. 12, pp. 1341-1352, 2010.

[33] A. Demirbas, "Waste management, waste resource facilities and waste conversion processes," Energy Conversion and Management, vol. 52, no. 2, pp. 1280-1287, 2011.

[34] S. M. Al-Rawe T. Al-Tayyar, "Two decades comparison of solid waste composition and generation in Mosul City," Tikrit Journal of Engineering Sciences, vol. 19, no. 1, pp. 13-24, 2012.

[35] A. K. Panda, R. K. Singh, and D. K. Mishra, "Thermolysis of waste plastics to liquid fuel: A suitable method for plastic waste management and manufacture of value added products-A world prospective," Renewable and Sustainable Energy Reviews, vol. 14, no. 1, pp. 233-248, 2010.

[36] E. Iakovou, A. Karagiannidis, D. Vlachos, A, Toka, and A. Malamakis, "Waste biomass-to-energy supply chain management: A critical synthesis," Waste management, vol. 30, no. 10, pp. 1860-1870, 2010.

[37] U. Arena, "Process and technological aspects of municipal solid waste gasification. A review," Waste Management, vol. 32, no. 4, pp. 625-639, 2012.

[38] S. Morrin, P. Lettieri, C. Chapman, and L. Mazzei, "Two stage fluid bed-plasma gasification process for solid waste valorisation: Technical review and preliminary thermodynamic modelling of sulphur emissions," Waste Management, vol. 32, no. 4, pp. 676-684, 2012.

[39] I. Janajreh, S. S. Raza, and A. S. Valmundsson, "Plasma gasification process: Modeling, simulation and comparison with conventional air gasification," Energy Conversion and Management, vol. 65, pp. 801-809, 2013.

[40] A. Z. Ya, "An innovative zero-emission energy model for a coastal village in Southern Myanmar," Global Journal of Research in Engineering, vol. 18, no. 2-F, pp. 23-35, 2018.

[41] A. Z. Ya, "Green improving by autonomous PV mini-grid model in Central Myanmar," Global Journal of Research in Engineering, vol. 18, no. 1-F, pp. 48-64, 2018.

[42] "2016 annual report MOE Iraq," Ministry of Electricity, Access in 6 November 2018, Available at: https://moelc.gov.iq/index.php?name=Pages\&op=page $\&$ pid=273.

[43] C. Ghenai and I. Janajreh, "Design of solar-biomass hybrid microgrid system in Sharjah," Energy Procedia, vol. 103, pp. 357-362, 2016. 